\title{
Strategic planning in urban forestry: A 21st century paradigm shift for small town Canada
}

\author{
by P.J.E. van Wassenaer ${ }^{1}$, L. Schaeffer ${ }^{2}$ and W.A. Kenney ${ }^{3}$
}

The pressures created by urban sprawl are leading to a reduction in forested land in Canada and North America. Poorly controlled land-use planning contributes to the haphazard urbanization of many small communities within commuting distance of major urban centres. Urban forests are largely ignored as an asset and the potential benefits they can offer to communities are often not acknowledged in the planning process. Relatively few communities across Canada have any form of urban forest management. A new definition of the urban forest is proposed that recognizes the need for an ecosystem approach to urban forest management and the integral role that humans play in that ecosystem. To facilitate the implementation of urban forest management plans in small communities, a simple strategic planning framework is presented. Using this approach, many small towns can maintain their rural character and benefit from a wealth of environmental, social and economic benefits.

Key words: urban forestry, community planning, forest benefits, strategic planning, ecosystem approach, forest fragmentation

Les pressions exercées par l'étalement urbain entraînent une réduction du territoire forestier au Canada et en Amérique du Nord. Une planification mal contrôlée de l'utilisation du territoire contribue à l'urbanisation anarchique de plusieurs petites agglomérations situées à une faible distance des principaux centres urbains. Les forêts urbaines sont en majorité ignorées au plan des actifs et les bénéfices potentiels qu'elles peuvent offrir aux agglomérations sont souvent non reconnus lors du processus de planification. Relativement peu d'agglomérations au Canada ont quelque forme d'aménagement forestier urbain. Une nouvelle définition des forêts urbaines est proposée qui reconnaît qu'il faut une approche écosystémique dans le cas de l'aménagement forestier urbain et que les humains jouent un rôle intégral dans cet écosystème. Afin de faciliter l'implantation des plans d'aménagement forestier urbain dans les petites agglomérations, un cadre de travail simple de planification stratégique est présenté. En utilisant cette approche, plusieurs petites villes peuvent maintenir leur caractère rural et bénéficier d'une multitude de retombées environnementales, sociales et économiques.

Mots clés: foresterie urbaine, planification communautaire, retombées forestières, planification stratégique, approche écosystémique, morcellement forestier

\section{Introduction}

The forest land base in Canada and North America is shrinking due to the growing pressures of land being converted into farm-holdings and then subsequently sub-urban housing developments. The loss of forested land has significantly fragmented forested ecosystems, reducing wildlife diversity, water quality and quantity, and the general health and wellbeing of people.

In Canada, as elsewhere, poorly controlled land-use planning and growing urban populations create pressure on adjoining forests and farmland. This pressure is most severe in those small communities that surround major urban centres. Small communities offer amenities that are absent in large cities while their proximity to urban centres still permits commuting as a viable option. The pressure for land, created by urban sprawl, is transferred to the smaller communities as commuters move outward from the city. Improving poorly developed infrastructures in smaller communities to meet the demands of these new residents requires large capital expenditures. Town councils often try to attract development activ-

\footnotetext{
${ }^{1}$ Urban Forestry Consultant, 544 Exbury Cres., Mississauga, Ont., L5G 2P4. E-mail: philip.vanwassenaer@utoronto.ca

${ }^{2}$ Private Consultant, $25259^{\text {th }}$ Ave., Castlegar, B.C., V1N 2Y7. E-mail: lees@kootenay.net

${ }^{3}$ Professor of Urban and Community Forestry. Faculty of Forestry, University of Toronto, 33 Willcocks St., Toronto Ontario, M5S 3B3. E-mail: akenney@utoronto.ca
}

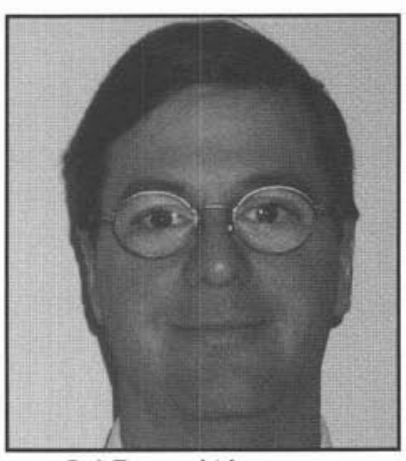

P.J.E. van Wassenaer

ities to help maintain and build better community infrastructure. This often creates a cycle in which local forests are converted into other land uses until towns become too large and people once again move outwards, looking for the amenities of another small community. The "leap-frogging" cycle is repeated and an urban sprawl paradigm is cre-

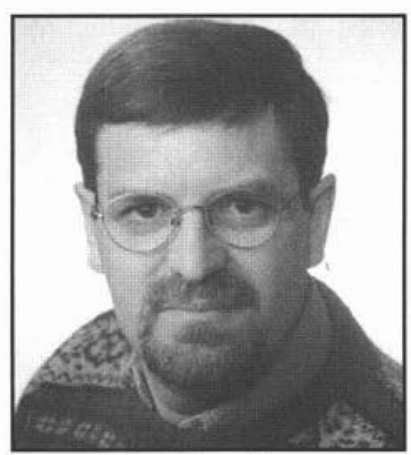

L. Schaeffer

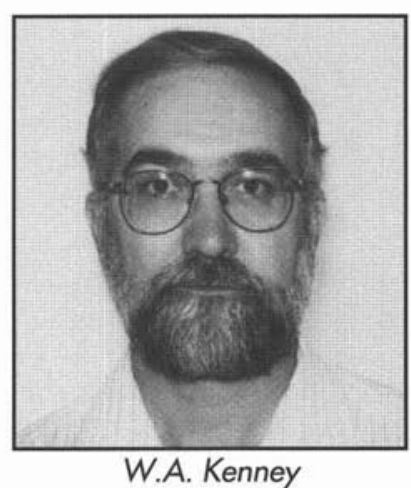
ated. To break this cycle of shrinking forest ecosystems, a new pattern needs to be created. The new paradigm should com- 
bine the requirements of urban growth with the need for ecosystem viability. To help facilitate the inclusion of the urban forest into this paradigm shift we propose a new definition of the urban forest and a simple strategic planning process that can be adopted by community planners. The adoption of the process and the new definition will help reduce the conversion of forested land and further fragmentation of these important ecosystems and allow for the future integration of these fragments into viable, strong ecosystems. It could also contribute to the reduction of urban sprawl by maintaining some of the amenities that attracted people to these small communities in the first place.

This paper is intended to highlight the importance of the urban forest resource and its associated benefits, and to provide a simple framework that can be used as the starting point for communities to develop their own urban forest management plans.

\section{Urban Forestry}

In the past, urban forestry was crudely defined as the management of street trees. Erik Jorgensen (1970) from the University of Toronto wrote that urban forestry in Canada "does not deal directly with city trees or with single tree management. It should deal with tree management in the entire area that is influenced and utilized by the urban population as well as the areas lying between these service areas and politically designated urban areas. The politically established boundaries for municipalities rarely include the entire geographical area influenced by urbanization."

Recently, this broader approach to urban forestry has been gaining acceptance because of its over-arching attempt to include the larger landscape. We would like to further this concept by incorporating ecosystem management principles into urban forest planning. One of the difficulties in managing the urban forest as an ecosystem lies in the fact that different individuals or agencies, often with different goals, administer their portion of the urban forest independently of the others. Small communities can include individuals or agencies managing conservation areas, street trees, public parks, trees on private residential lots, industrial lands and private and commercial woodlots. Another difficulty lies in the fact that small communities do not clearly identify their urbanized areas, thereby allowing "leapfrogging" development and the dissection of the larger landscape. A third difficulty in incorporating the urban forest ecosystem into a management framework is the lack of a defined vision in which the role of the urban forest within the community is clearly understood. As part of a new definition, we have determined that urban forest management in most small communities is comprised of three disparate parts: the unconsolidated administrative components, the physical area of urbanization, and the actual role that the urban forests play within the community. By drawing together these three parts into a new definition of the urban forest we can begin to enhance the social, economic and ecological well-being in the community. Therefore, we define the urban forest as:

A single consolidated forest composed of flora and fauna within the urbanized area that facilitates the social, economic and ecological well-being of the community.

This definition emphasizes that the community is an integral part of the urban forest ecosystem.

\section{Concepts and Benefits}

Most small communities have difficulty maintaining their small town character while expanding in size and population. The character of a small town captures the amenities that most urban refugees are seeking in their move away from the urban centres. Trees and forested ecosystems play a significant role in contributing to those amenities. In the old part of town, trees make a major contribution to the "rural feel" by softening visual impacts and adding spatial and seasonal variation. The charm of the town is greatly increased by majestic old trees that line the streets and create a "living tunnel" when their crowns meet over the streets. Treed parklands provide a place where residents can enjoy passive recreational opportunities such as bird watching and more active physical activities including hiking, cycling, and skiing.

Often overlooked by small communities are the economic benefits that have accrued to the community through the amount of, and access to, forested areas. The biological requirements of trees are often superseded by the urban infrastructural needs of roads, sewer systems, traffic lights etc. The unrealized economic benefits of trees and forested ecosystems, amenities sought by commuters leaving the urban core, are often lost during the development of urban infrastructure. Both can co-exist and benefit the community. Property values increase as the tree cover increases, or the distance to treed areas such as parks, creeks, or conservation areas is reduced (Darling 1973, Anderson and Cordell 1988). It is very common for developers to use these facts as selling points for their new properties. Houses found in old, treed neighbourhoods are highly desirable, as they are increasingly difficult to find. In addition to attracting residents and businesses, a town can benefit from trees because they add to increased property values (Petit et al. 1995) that, in turn, increase the property tax base.

The incorporation of ecosystem attributes such as wildlife habitat is another important benefit of an expanded urban forest. In most communities there are some important natural features which deserve protection because they harbour native wildlife populations. The expansion of the urban forest will help to protect and enhance these areas and provide linkages between fragmented ecosystems while maintaining the town's rural character. The urban forest is also capable of providing several important environmental services. Trees can reduce heating and cooling costs when appropriate species are chosen and planted in strategic locations (Akbari 1992). Shade trees can filter out incoming solar radiation in the summer and coniferous trees planted as windbreaks will reduce heat losses from cold winds in the winter (Heisler and Herrington 1976). Urban trees act as a natural noise filter (Huang et al. 1992, LongSheng et al. 1993) and can add to the quiet rural atmosphere that attracts new residents to a town.

While air pollution may not be as prevalent in smaller communities as in some of the larger urban centres nearby, the urban forest can contribute to the maintenance of air quality. Trees are very effective at sequestering carbon and a number of other airborne pollutants (McPherson and Nowak 1993, McPherson et al. 1994, Scott et al. 1998). Airborne dust particles are trapped on tree surfaces and then washed into the soil by precipitation (Akbari 1992).

The urban forest also contributes to the mitigation of negative hydrological impacts of urbanization by reducing runoff, improving the quality of storm-water, and reducing the need 


\begin{tabular}{|c|c|c|c|c|c|}
\hline Criteria & Low & Moderate & Good & Optimal & Key Objectives \\
\hline $\begin{array}{l}\text { Ecosystem } \\
\text { diversity }\end{array}$ & $\begin{array}{c}\text { No assessment } \\
\text { of existing } \\
\text { habitat }\end{array}$ & $\begin{array}{l}\text { Assessment and, hiding } \\
\text { identification of key } \\
\text { habitat features } \\
\text { (breeding, display } \\
\text { cover etc.) }\end{array}$ & $\begin{array}{l}\text { Assessment and } \\
\text { integration of } \\
\text { habitat features } \\
\text { into a landscape } \\
\text { context }\end{array}$ & $\begin{array}{l}\text { Connectivity of } \\
\text { landscape } \\
\text { features and } \\
\text { restoration of } \\
\text { natural habitats }\end{array}$ & $\begin{array}{c}\text { Habitat } \\
\text { protection }\end{array}$ \\
\hline $\begin{array}{l}\text { Species } \\
\text { monitoring }\end{array}$ & $\begin{array}{l}\text { No } \\
\text { assessment } \\
\text { or status of } \\
\text { species } \\
\text { utilizing the } \\
\text { urban forest }\end{array}$ & $\begin{array}{l}\text { Species status } \\
\text { and population } \\
\text { assessments of } \\
\text { major wildlife } \\
\text { species in the } \\
\text { forest }\end{array}$ & $\begin{array}{l}\text { Comprehensive } \\
\text { assessment, } \\
\text { including lesser- } \\
\text { known species }\end{array}$ & $\begin{array}{c}\text { Long-term } \\
\text { assessment of } \\
\text { species status } \\
\text { and population } \\
\text { changes }\end{array}$ & $\begin{array}{c}\text { Assessment of } \\
\text { viable species } \\
\text { populations }\end{array}$ \\
\hline $\begin{array}{l}\text { Species } \\
\text { protection } \\
\text { and policy }\end{array}$ & $\begin{array}{l}\text { No policy or } \\
\text { policy not } \\
\text { enforced }\end{array}$ & $\begin{array}{l}\text { Enforced policy } \\
\text { present with } \\
\text { specifics on } \\
\text { invasive and } \\
\text { exotic species }\end{array}$ & $\begin{array}{c}\text { Native species } \\
\text { protected and } \\
\text { promoted in all } \\
\text { projects }\end{array}$ & $\begin{array}{l}\text { Re-introduction } \\
\text { of native species }\end{array}$ & $\begin{array}{l}\text { Conserve } \\
\text { naturally } \\
\text { existing } \\
\text { species }\end{array}$ \\
\hline
\end{tabular}

for man-made erosion control structures (Lormand 1988, Xiao et al. 1998).

While some of these benefits lend themselves to quantification, others are not so readily assessed. Current research cannot always quantify benefits and costs, but trends indicate that actions are necessary to promote a healthy urban forest for the future. When dollar values can be assigned to these functions it will be much easier for planners and managers to treat this renewable resource as a part of the urban budget that requires greater attention. It seems that at present, in many places, urban vegetation ranks near the bottom of the list of priorities for city planners and managers. The benefits of the urban forest have not been fully incorporated into our communities at the planning phase.

Unfortunately, the urban infrastructure is designed to accommodate engineered structures such as roads, utilities and buildings, with little consideration for the biological requirements of trees. Newly planted trees are rarely given the proper space, soil, water or nutrients necessary for long-term survival. An average tree in a "hardscaped" downtown setting lives about seven years, an average city tree lives 32 years, and the same species of tree in a rural setting can live up to 150 years (Skiera and Moll 1992). Maximum benefits are derived from large trees that have larger canopies and greater leaf areas than small trees (Kenney 2000b, this issue).

Despite an increased awareness of urban forestry and its benefits, many cities are experiencing a decline in the health of their urban forests (Kielbaso 1990). To prevent this trend from continuing, new policies must be implemented to place a higher priority on trees. The wealth of information on the benefits of urban forestry needs to be used to educate the general public and policy makers so that they can make informed decisions about this valuable resource. In a recent survey of Canadian municipalities with populations greater than 4000 , one of the authors (Kenney 2000a) found that in communities with less than 100000 people, only one third reported having any strategic municipal forest plan and communities with over 100000 inhabitants reported that less than $50 \%$ were engaged in urban forest management. Similarly, Doherty et al. (2000) found that in the state of Massachusetts, when looking at com- munities with 10000 or more inhabitants, $72 \%$ had no urban forest inventory and $83 \%$ had no urban forest management plan. Considering only 10 to $20 \%$ of the urban forest resource comes under the jurisdiction of the municipality (McPherson 1998), it is obvious that little of this valuable resource is currently under any planning regime.

\section{Strategic Planning Process}

As towns develop strategies for growth and development into the 21st Century, the urban forest benefits can contribute to the environmental, social, and economic needs of the community. We feel that the following outline can aid in the beneficial development and incorporation of the urban forest into a small community. The eight stages in this process are:

1. Identification of the various attributes of the urban forest.

2. Assessment of relevant resource data where it exists.

3. Creation of a vision in which the needs and desires of the community can be reflected in an urban forest ecosystem.

4. Determination of the current status of the various components and their sustainability.

5. Identification of the gaps between the vision and the current status.

6. Creation or definition of an administrative vehicle to close these gaps.

7. Formulation of an operational plan that incorporates the community's goals.

8. Implementation and monitoring of the plan.

The first step in the creation of a strategic plan is to identify all of the various attributes of the urban forest within the planning area. These attributes include existing green spaces, as well as the treed or untreed areas between green spaces. A variety of management strategies, sometimes each with differing objectives and/or goals, usually exist for these components. The goal of each management strategy needs to be examined in order to determine the impact it has upon the urban forest ecosystem.

In many cases, there is only a rudimentary database or knowledge of the forested ecosystem within each of the components. 
The municipality may have an inventory for street trees, parks and conservation lands, but their level of detail may vary. Even if an inventory of the municipally owned trees does exist, it will only represent a small portion of the urban forest (McPherson 1998). As is the case with any renewable resource, an inventory is an essential tool for the formulation of management strategies. It will identify details of the structure of the urban forest, which are necessary for the planning of management activities to achieve specific goals. These details may include species composition, the mixture of native and non-native species, age structure, tree condition, location, size, management history, and habitat. Inventories may also reveal other valuable assets, such as the presence of rare or endangered species that may otherwise be overlooked.

Once the various components and their assets have been identified, the next step requires the community to create a unifying vision of its urban forest. Most communities can start by identifying a unique component of their urban forest as a focal point. The management of other components should then be integrated with this feature to form a cohesive urban forest. For example, a significant forest stand in the urbanized area can be buffered from external influences by the appropriate distribution of parkland dedications as development occurs on its periphery. Linkages between components and the surrounding landscape should be established as part of this vision. Vision statements can be amalgamated from higher level plans and differing management regimes, but must ultimately reflect the needs of the community and therefore must incorporate public participation in all phases of their development.

The next step in the process should be an assessment of the current status of the various components of the urban forest. Clarke et al. (1997) have developed a set of criteria and objectives with performance indicators for three of these components: 1) the community framework, 2) the vegetation resource, and 3) resource management. However, in their discussion of vegetation and resources management, the focus is solely on the tree resource. If we are to consider the urban forest as an ecosystem, we must consider more than just the tree component. Using a similar style, we expanded the model to include wildlife management (Table 1). Ultimately, a similar approach should be used to incorporate other biotic and abiotic components.

Stage 5 involves the identification of gaps between the current status and the communities' vision of their urban forest. By identifying the deficiencies in information, knowledge or skills, the community can formulate a management plan with specific objectives and goals directed at bridging any gaps identified at this stage.

Stage 6 involves the creation or definition of an administrative vehicle through which the community can progress from the disparate management of various components to the cohesive management of the urban forest as a single entity. The community may already have a mechanism appropriate for the development of the urban forest or it may have to create one. This might take the form of a community board, an urban forest management team, or an inter-government working group. In any of these forums, the key objectives should be consensus building, joint problem solving, and negotiation.

The seventh stage requires that, once the specific goals of the community have been ascertained, an operational plan must be initiated. Within that plan, an administrative process, budget, timeline, and a monitoring process must be defined to help the community achieve its vision.

The final stage is the implementation of the plan. In order to identify any shortcomings or problems within the implementation plan we recommend that it be carried out in increments, or as a series of pilot projects. This approach will create an opportunity to adapt the process such that any changes that may arise from a monitoring programme can be incorporated back into the planning process. These steps are not all-inclusive and not meant to be a cookbook recipe to success.

\section{Conclusions}

Forested land in Ontario and North America will continue to shrink due to the growing pressures of land conversion and poorly controlled land-use planning unless we can break the cycle of urban sprawl. This pressure is most severe in those small communities that surround major urban centres because they offer the amenities desired by most people. Fragmented forests, reduced wildlife diversity, reduced water quality and quantity, and the reduced general health and well being of people are the negative results of this process. In order to break that cycle we have redefined the urban forest as a single consolidated forest composed of flora and fauna within the urbanized area that facilitates the social, economic and ecological well-being of the community. By adopting such a definition and by implementing an urban forest management plan, we believe that many small towns can maintain their rural character, reap a wealth of environmental, social and economic benefits, and better integrate themselves into the larger landscape mosaic.

\section{References}

Akbari, H., (ed.). 1992. Cooling our communities: A guidebook on tree planting and light -coloured surfaces. U.S.A. E.P.A. Policy, Planning, And Evaluation (PM-221). 217 p.

Anderson, L.M. and H.K. Cordell. 1988. Influence of trees on residential property values in Athens, Georgia (USA): A survey based on actual sales prices. Landscape and Urban Planning 15: 153-164. Clark, J.R., N.P. Matheny, G. Cross and V. Wake. 1997. A model of urban forest sustainability. Journal of Arboriculture 23 (1): 17-30.

Darling, A.H. 1973. Measuring benefits generated by urban waterparks. Land. Econ. 49: 22-34.

Doherty, K.D., H.D.P. Ryan and D.V. Bloniarz. 2000. Tree wardens and utility arborists: A management team for street trees in Massachusetts. Journal of Arboriculture 26 (1): 38-47.

Heisler, G.M. and L.P. Herrington. 1976. Selection of trees for modifying metropolitan climates. In F.S. Sanatour (ed.). Better trees for metropolitan landscapes. pp. 31-37. USDA Forest Service Gen. Techn. Rprt. NE 22.

Huang, J., R. Ritschard, N. Sampson and H. Taha. 1992. The benefits of urban trees. In H. Akbari, H.S. Davis, S. Dorsano, J. Huang and S. Winnet. (eds.). Cooling Our Communities. pp. 27-42. US Environmental Protection Agency. Policy, Planning and Evaluation (PM-221). 22P-2001. Washington, D.C. 217 p.

Jorgensen, E. 1970. Urban forestry in Canada. In Proceedings of the $46^{\text {th }}$ International Shade Tree Conference. pp. 43a-51a.

Kenney, W.A. 2000a. The state of Canada's municipal forests 1996 to 1998. For Chron. 76(2): 231-234.

Kenney, W.A. 2000b. Leaf Area Density as an urban forestry planning and management tool. For. Chron. 76(2): 235-239

Kielbaso, J. J. 1990. Trends and issues in city forests. Journal of Arbori- 
culture 16(3): 69-76.

Long-Sheng Mao, Yong Gao, and Wen-Quan Sun. 1993. Influences of street tree systems on summer micro-climate and noise attenuation in Nanjing City, China. Arboricultural Journal 17(3): 239-251. Lormand, J.R. 1988. The effects of urban vegetation on stormwater runoff in an arid environment. Journal of Arboriculture 14(6): 235-242.

McPherson, E.G. 1998. Structure and sustainability of Sacramento's urban forest. Journal of Arboriculture 24(4): 174-189.

McPherson, E.G. and D.J. Nowak. 1993. Value of urban greenspace for air quality improvement: Lincoln Park, Chicago. Arborist News. 2(6): 30-32.

McPherson, E.G., D.J. Nowak and R.A. Rowntree (eds.). 1994. Chicago's urban forest ecosystem: Results of the Chicago urban forest climate project. Gen. Techn. Rprt. NE-186. Radnor, P.A.: U.S. Dept. of Ag., Forest Service, Northeastern Forest Experiment Station. 201 p.
Petit, J., D.L. Bassert and C. Kollin. 1995. Building greener neighborhoods: trees as part of the plan. National Academy of Home Builders and American Forests. 117 p.

Scott, K.I., E.G. McPherson and J.R. Simpson. 1998. Air pollutant uptake by Sacramento's urban forest. Journal of Arboriculture 24(4): 224-234.

Skiera, B. and G. Moll. 1992. The sad state of city trees. American Forests 98 (3/4): 61-64.

Xiao, Q., E.G. McPherson, J.R. Simpson and S.L. Ustin. 1998. Rainfall interception by Sacramento's urban forest. Journal of Arboriculture 24(4): 235-244. 